\title{
Mathematical models for prediction of trihalomethanes in drinking water
}

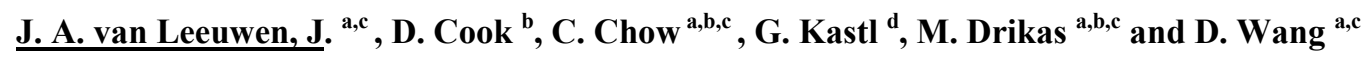 \\ ${ }^{a}$ SA Water Centre for Water Management and Reuse, NBE, University of South Australia, South Australia. \\ ${ }^{b}$ Australian Water Quality Centre, SA Water, South Australia. \\ ${ }^{c}$ State Key Laboratory for Environmental Aquatic Chemistry, CAS, China. \\ ${ }^{d}$ MWH, Queensland, Australia \\ Email: john.vanleeuwen@unisa.edu.au
}

\begin{abstract}
Use of chlorine for disinfection of water for potable supply is commonly practiced in Australia and elsewhere. Chlorine $\left(\mathrm{Cl}_{2}\right)$ is an inexpensive and effective disinfectant but will decay in the distribution system due to its reaction with natural organic matter remaining in water after the water has been treated, normally by coagulation and flocculation. The decay kinetics of chlorine is a function of several physico-chemical factors of water quality, including organic content, temperature and $\mathrm{pH}$.

In the reaction of chlorine with organic matter, halogenated disinfection by-products (DBPs) can form including trihalomethanes (THMs), haloacetic acids (HAAs) and haloacetonitriles (HANs). These are considered important compounds from adverse human health perspectives with total and individual compound concentrations being regulated in many countries. Because of the importance of halogenated DBPs in drinking water, they have been the subject of much research over recent decades, including modelling of their formation for prediction purposes. Models developed have included statistically fitted ones, incorporating a range of key variables known to affect their formation. However, the mechanisms involved in formation of DBP appear to be numerous, making the development of a model for both total and individual compound formation that can be applied practically, a significant challenge.
\end{abstract}

In this paper, we report a modelling approach to describe the formation of THMs, for total and for the four compound species, chloroform, bromodichloromethane, chlorodibromomethane and bromoform. Data available from chlorine decay experiments that had been conducted on several Australian waters with temperature and $\mathrm{pH}$ controlled and at various bromide $(\mathrm{Br})$ concentrations to $\sim 0.7 \mathrm{mg} / \mathrm{L}$ were used with for model development.

In contrast to models generally reported in the literature where models relate absolute THM values to water quality parameters, here model development is based on standardization of the formation of THM at a nominal set of water quality conditions, i.e. formation of total THMs at $0.1 \mathrm{mg} \mathrm{L}^{-1} \mathrm{Br}, \mathrm{pH} 7$ and temperature at $15^{\circ} \mathrm{C}$ assigned as $100 \%$ formation. The impacts of different $\mathrm{pH}$ and temperature levels and bromide concentrations on the $\%$ formation of total THM (TTHM) were determined. This was done with aim to enable assessment of the impacts of each influencing parameter on total THM formation. From this information, the impacts of these parameters may be evaluated for other waters with different water quality conditions $(\mathrm{pH}$, temperature, $\mathrm{Br}$ concentration) in context of chlorine decay following disinfection by chlorination.

For modelling of the formation of individual THM compounds, mathematical functions were determined for relationships between $\mathrm{Br} / \mathrm{Cl}_{2}$ decay ratios with the percentage formations of chloroform and bromoform, and with the ratios of formation of chlorodibromomethane to bromodichloromethane. From these functions, the absolute formations of each of the four THM species can be estimated from the predicted total THM formed, based on chlorine decay, bromide concentration, temperature and $\mathrm{pH}$ of the water. Bromide was found to have a key role in both TTHM and the individual species formed. In this study few data points of controlled temperature and $\mathrm{pH}$ were available and consequently simple linear relationships for these were assumed. Future improved model development would require higher resolution data for these parameters.

Keywords: Disinfection by-product, THMs, Chlorine decay. 


\section{INTRODUCTION}

The formation of disinfection by products (DBP) is an important issue to the water industry as these compounds may be of health concern to the community (ADWG, 2004). The concentrations of key DBP compounds in drinking water are regulated in many countries while in others such as Australia, guideline levels have been set by national health authorities, with some states moving to regulation. The type of compounds formed is a function of the disinfection process used, particularly when chemical disinfection is applied such as chlorine and chloramine. Chlorine is the most widely applied chemical disinfectant in the supply of drinking water based on its efficiency and low cost. Nonetheless, it has significant drawbacks including its rapid decline in concentration in the water distribution system through rapid and slow reactions with organics present in the water, and consequential formation of DBP in this process (Fisher et al. 2004). Other physical and chemical factors also affect DBP formation including $\mathrm{pH}$ and temperature (Sohn et al. 2004). The presence of bromide further impacts on DBPs in the presence of free chlorine, as it is oxidized to bromine which then oxidizes organics producing brominated DBPs. Key DBPs formed from the use of chlorine include trihalomethanes (THM), haloacetic acids (HAA) and haloacetonitriles (HAN). There have been numerous efforts reported in the literature to develop models for the prediction of THMs in drinking waters, as totals (Sohn et al. 2004; Uyak et al. 2005; Sun et al. 2009) but much less for models of individual compounds that comprise the group. Here we report a novel modelling approach to describe the total formation of trihalomethanes in surface water before and after blending with reverse-osmosis treated seawater. Also reported is the modelling of the formation of individual THM compounds, chloroform, bromodichloromethane, chlorodibromomethane and bromoform.

\section{MATERIALS AND METHODS}

Data used for development of models of total trihalomethane (TTHM) formation and the abundances of the four compound species, chloroform, bromoform, chlorodibromomethane and bromodichloromethane were acquired from laboratory investigation. These data were obtained from controlled experiments where surface waters from several locations in Victoria and South Australia were tested as collected or spiked with bromide (to 0.5 $\mathrm{mg} \mathrm{L} \mathrm{L}^{-1}$ ), temperatures controlled at $15^{\circ} \mathrm{C}, 25^{\circ} \mathrm{C}$ and $30^{\circ} \mathrm{C}$ and $\mathrm{pH}$ controlled at $7,8.5$ and 10 . Under these conditions, chlorine decay tests were performed as described by Eaton et al. (1998) and Daly et al. (2007) and at various times up to 10 days of chlorine decay, the concentrations of the four THM compounds were determined. THM species were determined using an automated headspace sampler (Perkin Elmer, TurboMatrix 110) followed by gas-chromatography with electron-capture detection (Perkin Elmer Clarus ${ }^{\circledR} 500$ GC).

In the attempt to develop a more generic model as opposed to site-specific one, data were standardised to percentages based on a nominal set of test conditions (i.e. formation of TTHM at $\mathrm{Br}, 0.1 \mathrm{mg} \mathrm{L^{-1 }}, \mathrm{pH}^{7}$, temperature $15^{\circ} \mathrm{C}$ was assigned $100 \%$ formation) and from this, $\%$ THM formations for other test conditions were assigned.

Treated water samples from a water treatment plant (WTP) in South Australia that uses a conventional treatment process (coagulation, flocculation, sedimentation, filtration) were collected, blended with reverse-osmosis treated seawater (using second pass permeate of a reverse osmosis pilot plant) and then analysed for a range of water quality parameters including bromide, $\mathrm{pH}$ and natural organic concentration. These samples provided waters with a wide range of qualities that were then used in chlorine decay tests and THM formation at various reaction times up to 10 days.

Data of water samples that had been spiked with bromide and where the $\mathrm{pH}$ and temperatures were controlled were used firstly to determine the effects of bromide with chlorine consumption on TTHM formation at controlled $\mathrm{pH}$ and temperature. The aim in this approach was to develop models of the trend effects of each water quality parameter, as opposed to grouping of the three parameters through statistical methods, such as multivariate or polynomial techniques. Following this, trend analyses were conducted of THM specie formation based on temperature, $\mathrm{pH}$ and bromide concentration.

Mathematical relationships were established between the relative abundances of the four species, as percentages, with the ratio of the concentrations of $\mathrm{Br}$ to $\mathrm{Cl}_{2}$ reacted. 


\section{RESULTS AND DISCUSSION}

The impact of bromide $(\mathrm{Br})$ concentration on the formation of TTHM was investigated from data acquired of several surface waters spiked with bromide at concentrations ranging between 0 and $0.5 \mathrm{mg} \mathrm{L}^{-1}$. These waters had been tested at controlled $\mathrm{pH}(7$ and 8.5$)$ and temperature $\left(15^{\circ} \mathrm{C}\right.$ and $\left.30^{\circ} \mathrm{C}\right)$, set chlorine doses and reaction times, where TTHMs were subsequently quantified. For this data set, formations of TTHM under the various conditions of $\mathrm{Br}, \mathrm{pH}$ and temperature were all standardized to percentages based on the TTHM formed at $\mathrm{pH} 7$, $\mathrm{Br}$ at $0.1 \mathrm{mg} \mathrm{L}^{-1}$ and $15^{\circ} \mathrm{C}$ being assigned $100 \%$. Limitation in data availability led to an assumption being made that trends between data points, e.g. between $\mathrm{pH} 7$ and 8.5 , and between $15^{\circ} \mathrm{C}$ and $30^{\circ} \mathrm{C}$ were of straight lines $(\mathrm{Y}=\mathrm{M} . \mathrm{X}+\mathrm{C}$, where $\mathrm{Y}$ is the output parameter e.g. \%TTHM, $\mathrm{M}$ is gradient, $\mathrm{X}$ is input parameter e.g. bromide concentration and $\mathrm{C}$ is $\mathrm{Y}$ intercept).

The following equations were determined to describe relationships between TTHM formation (as \% of standardized formation, detailed above) and $\mathrm{Br}(\mathrm{mg} / \mathrm{L})$ concentration at $\mathrm{pH}$ and temperature $\left(\mathrm{T},{ }^{\circ} \mathrm{C}\right)$ conditions tested and for set $\mathrm{Cl}_{2}$ addition and reaction time (shown in Figure 1).

For $15^{\circ} \mathrm{C}, \mathrm{pH} 7, \% \mathrm{TTHM}=249.4 \times \mathrm{Br}+74.2$, where $\mathrm{Br}$ is bromide concentration $\left(\mathrm{mg} \mathrm{L}^{-1}\right)$

For $15^{\circ} \mathrm{C}, \mathrm{pH} 8.5, \% \mathrm{TTHM}=257.0 \times \mathrm{Br}+103.8$

For $30^{\circ} \mathrm{C}, \mathrm{pH} 7, \% \mathrm{THM}=199.7 \times \mathrm{Br}+77.1$

For $30^{\circ} \mathrm{C}, \mathrm{pH} 8.5, \% \mathrm{THM}=208.7 \times \mathrm{Br}+82.5$

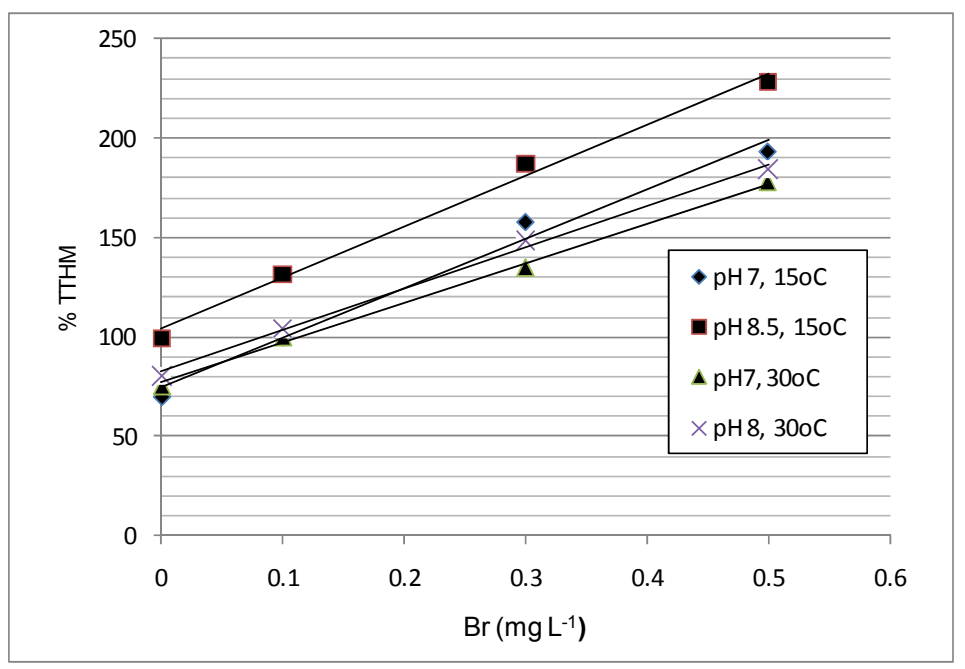

Figure 1. Relationships between bromide concentrations and \%TTHM formation relative to standardized conditions ( $\mathrm{pH} 7, \mathrm{Br}$ at $0.1 \mathrm{mg} \mathrm{L}^{-1}$ and $\left.15^{\circ} \mathrm{C}, 100 \% \mathrm{TTHM}\right)$.

From the above, further equations were established to relate $\mathrm{pH}$ between 7 and 8.5 with $\% \mathrm{TTHM}$, at $15^{\circ} \mathrm{C}$ and $30^{\circ} \mathrm{C}$, as follows,

For $\mathrm{pH}$ between 7 and 8.5 , at $15^{\circ} \mathrm{C}$, the relationship of the gradients, $\mathrm{M}$,

of equations (1) and (2) was determined as follows, $\mathrm{M}=5.02 \mathrm{x} \mathrm{pH}+214.3$,

For $\mathrm{pH}$ between 7 to 8.5 , at $15^{\circ} \mathrm{C}$, the relationship of the $\mathrm{Y}$ intercept value, $\mathrm{C}$,

of equations (1) and (2) was determined as follows, $\mathrm{C}=11.1 \mathrm{x} \mathrm{pH}+0.992$,

For $\mathrm{pH}$ between 7 and 8.5 at $30^{\circ} \mathrm{C}$, the relationship of the gradients, $\mathrm{M}$,

of equations (3) and (4) was determined as follows, $\mathrm{M}=5.98 \mathrm{x} \mathrm{pH}+157.8$,

For $\mathrm{pH}$ between 7 to 8.5 at $30^{\circ} \mathrm{C}$, the relationship of the $\mathrm{Y}$ intercept value, $\mathrm{C}$, of equations (1) and (2) was determined as follows, $\mathrm{C}=77.9$

For model development that describes TTHM $\mu \mathrm{g} / \mathrm{L}$ formation, the following steps were carried out:

Step 1. For $\mathrm{pH} i$ value over the range 7 to 8.5 and for $15^{\circ} \mathrm{C}$, Equation 5 is used to calculate $\mathrm{M}_{(\mathrm{pHi}, 15)}$ and for $30^{\circ} \mathrm{C}$, Equation 7 is used to calculate $\mathrm{M}_{(\mathrm{pHi}, 30)}$.

Step 2. For $\mathrm{pH} i$ over the range 7 to 8.5 and for $30^{\circ} \mathrm{C}$, Equation 6 is used to calculate $\mathrm{C}_{(\mathrm{pHi}, 15)}$ and for $30^{\circ} \mathrm{C}$, $\mathrm{C}=77.9$ was used.

Step 3. The effects of temperature $\left(\mathrm{T}_{j}\right)$ were determined over the range of $15^{\circ} \mathrm{C}$ to $30^{\circ} \mathrm{C}$, as follows, 
$\mathrm{M}(\mathrm{T} j)=\left[\left(\mathrm{M}_{(\mathrm{pHi}, 15)}-\mathrm{M}_{(\mathrm{pHi}, 30)}\right) / 15\right]+\left[\mathrm{M}_{(\mathrm{pHi}, 15)}-15+\left(\mathrm{M}_{(\mathrm{pHi}, 15)}-\mathrm{M}_{(\mathrm{pHi}, 30)}\right) / 15\right]$

$\left.\mathrm{C}(\mathrm{T} j)=\left[\left(\mathrm{C}_{(\mathrm{pHi}, 15)}-77.9\right) / 15\right]+\left[\mathrm{C}_{(\mathrm{pHi}, 15)}-15+\left(\mathrm{C}_{(\mathrm{pHi}, 15)}-77.9\right)\right) / 15\right]$

Step 4. For bromide ion concentration, $\mathrm{Br}_{k}, \% \mathrm{TTHM}_{x}=\mathrm{M}\left(\mathrm{T}_{j}\right) \cdot \mathrm{Br}_{k} \cdot \mathrm{Br}_{\mathrm{IMF}}+\mathrm{C}\left(\mathrm{T}_{j}\right)$,

where $\% \mathrm{TTHM}_{\mathrm{x}}$ is the $\%$ THM formation of a water sample, $\mathrm{Br}_{\mathrm{IMF}}$ is an impact factor of $\mathrm{Br}$ on TTHM formation for a specific water.

Step 5. From TTHM vs $\mathrm{Cl}_{2}$ dose (to $6 \mathrm{mg} / \mathrm{L}$ ) and $\mathrm{Cl}_{2}$ reacted data of a surface water sample (collected from South Australia) with average $\mathrm{Br}, 0.157 \mathrm{mg} \mathrm{L}^{-1}, \mathrm{pH} 7.74$ and temperature, $21.9^{\circ} \mathrm{C}$, the $\% \mathrm{TTHM}_{D}$ was calculated to be $124.4 \%$, compared with the standardized conditions $\left(\mathrm{Br}, 0.1 \mathrm{mg} \mathrm{L}^{-1}, \mathrm{pH} 7\right.$ and temperature, $15^{\circ} \mathrm{C}$, being $100 \%)$.

Step 6. The ratio of $\% \mathrm{TTHM}_{\mathrm{x}}$ to $\% \mathrm{TTHM}_{D}$ is used as a multiplication factor $\left(\mathrm{R}_{1}\right)$ for $\mathrm{THM}$ formation at $\mathrm{pH}_{i}, \mathrm{~T}_{j}$ and $\mathrm{Br}_{k}$.

Step 7. The TTHM formation of a water where the $\mathrm{Cl}_{2}$ consumed, $\mathrm{pH}$ (7 to 8.5), temperature $\left(15^{\circ} \mathrm{C}\right.$ to $\left.30^{\circ} \mathrm{C}\right)$ and $\mathrm{Br}$ concentration (to $\sim 0.7 \mathrm{mg} \mathrm{L}^{-1}$.), are known, is calculated from the following equation,

$\mathrm{TTHM}_{\mathrm{x}}=\mathrm{R}_{1} \mathrm{x}\left[\left(\mathrm{C}_{\mathrm{THM}}, \mu \mathrm{g} \text { THM } @ 1 \mathrm{mg} \mathrm{Cl} \text { consumed }\right) \times \text { Total } \mathrm{Cl}_{2} \text { mg consumed }\right]^{\wedge} \mathrm{R}_{\mathrm{THM}}$,

where $\mathrm{R}_{\mathrm{THM}}=\mathrm{THM}$ formation rate variable, $\mathrm{C}_{\mathrm{THM}}=\mathrm{THM}$ formation constant, $\mathrm{C}_{\mathrm{THM}}$ and $\mathrm{R}_{\mathrm{THM}}$ are determined from model fitting of data of a specific water. In the model developed, the $\mathrm{C}_{\mathrm{THM}}$ and $\mathrm{R}_{\mathrm{THM}}$ are applied as input variables that can be adjusted for different waters if required. For the samples of the South Australian water source tested, values determined were as follows: $\mathrm{C}_{\mathrm{THM}}=32 \mu \mathrm{g} \cdot \mathrm{L}^{-1}$, and $\mathrm{R}_{\mathrm{THM}}=0.844$.

A flow diagram of the steps taken in the development of the TTHM model is shown in Figure 2.

There are four THM compounds, chloroform, bromodichloromethane, chlorodibromomethane and bromoform. The distribution of these is a function of the ratio of bromide concentration and the chlorine reacted (or consumed). With a higher ratio of chlorine, more chloroform is formed while a higher ratio of bromide leads to higher formation of bromoform. The relative distributions of bromodichloromethane and chlorodibromomethane are also a function of relative concentrations of bromide to chlorine reacted.

For model development for prediction of the relative abundances of the four THM compounds, the following steps were carried out from data of compounds obtained at $15^{\circ} \mathrm{C}$ and $25^{\circ} \mathrm{C}$.

Step 8. From data of $\mathrm{Br} / \mathrm{Cl}_{2 \text { (reacted) }}$ and $\% \mathrm{CHCl}_{3}$ formed, a relationship was established for $25^{\circ} \mathrm{C}$,

i.e. $\% \mathrm{CHCl}_{3}=\operatorname{EXP}\left(\mathrm{A}_{1}-\mathrm{B}_{1} \times\left(\mathrm{Br} / \mathrm{Cl}_{2}\right)^{\wedge} 0.5\right)$, where $\mathrm{A}_{1}=4.61 ; \mathrm{B}_{1}=9.53$

and for $15^{\circ} \mathrm{C}, \quad \% \mathrm{CHCl}_{3}=\operatorname{EXP}\left(\mathrm{A}_{2}-\mathrm{B}_{2} \times\left(\mathrm{Br} / \mathrm{Cl}_{2}\right)^{\wedge} 0.5\right), \mathrm{A}_{2}=4.61, \mathrm{~B}_{2}=10.28$

(13)

Step 9. Similarly, from data of $\mathrm{Br} / \mathrm{Cl}_{2 \text { (reacted) }}$ and $\% \mathrm{CHBr}_{3}$ formed, a relationship was established for $25^{\circ} \mathrm{C}$, i.e. $\% \mathrm{CHBr}_{3}=\mathrm{A}_{3} \times\left(1-\mathrm{EXP}\left(-\mathrm{B}_{3} \times \mathrm{Br} / \mathrm{Cl}_{2}\right)\right.$, where $\mathrm{A}_{3}=99.4, \mathrm{~B}_{3}=5.47$

and for $15^{\circ} \mathrm{C}, \% \mathrm{CHBr}_{3}=\mathrm{A}_{4} \times\left(1-\operatorname{EXP}\left(-\mathrm{B}_{4} \times \mathrm{Br} / \mathrm{Cl}_{2}\right), \mathrm{A}_{4}=100.0, \mathrm{~B}_{4}=7.64\right.$

Step 10. To account for temperature effects and based on the available data above,

for a temperature, $\mathrm{T}^{\circ} \mathrm{C}$, between $15^{\circ} \mathrm{C}$ to $25^{\circ} \mathrm{C}$,

$\% \mathrm{CHCl}_{3}=\operatorname{EXP}\left(\mathrm{A}_{\mathrm{i}}-\mathrm{B}_{\mathrm{i}} \times\left(\mathrm{Br} / \mathrm{Cl}_{2}\right)^{\wedge} 0.5\right)$, where $\mathrm{A}_{\mathrm{i}}=4.605$ and $\mathrm{B}_{\mathrm{i}}=-0.075 \times \mathrm{T}^{\circ} \mathrm{C}+11.4$

and $\% \mathrm{CHBr}_{3}=\mathrm{A}_{\mathrm{j}} \times\left(1-\mathrm{EXP}\left(-\mathrm{B}_{\mathrm{j}} \times \mathrm{Br} / \mathrm{Cl}_{2}\right)\right.$, where $\mathrm{A}_{\mathrm{j}}=99.7$ and $\mathrm{B}_{\mathrm{j}}=-0.217 \times \mathrm{T}^{\circ} \mathrm{C}+10.9$

Step 11. For determination of the relative abundances of chlorodibromomethane and bromodichloromethane, the relation between the ratio $\mathrm{Br} / \mathrm{Cl}_{2 \text { (reacted) with the ratio of } \mathrm{CHBr}} \mathrm{Cl} / \mathrm{CHBrCl}_{2}$ was determined for $25^{\circ} \mathrm{C}$ data only (the $15^{\circ} \mathrm{C}$ data was too variable and limited in range to be useful).

i.e. $\mathrm{CHBr}_{2} \mathrm{Cl} / \mathrm{CHBrCl}_{2}=-0.021732+7.39589 \times \mathrm{Br} / \mathrm{Cl}_{2} \wedge 0.5$

From steps 8 and 9 , the percentage abundances of chloroform and bromoform are determined, respectively. From the calculated ratio of chlorodibromomethane to bromodichloromethane, their individual percentage abundances were calculated from their total percentage abundance, i.e. $\%\left(\mathrm{CHBr}_{2} \mathrm{Cl}+\mathrm{CHBrCl}_{2}\right)=(100 \%-$ $\% \mathrm{CHCl}_{3}-\% \mathrm{CHBr}_{3}$ ). From the model percentages of the four compounds and the TTHM, the concentrations of the four compounds can then be calculated (see Figure 3).

Comparison of model fitted data with laboratory data for water samples of the South Australian water source with and without Br being spiked are shown in Table 1 (unblended) and Table 2 (blended, 75\% to 25\%). Of the 32 laboratory data sets, about $75 \%$ of the modelled data were similar to actual data. For TTHMs, $\mathrm{R}^{2}$ values for the relationship between actual versus model fitted data were 0.62 (unblended waters) and 0.75 (blended waters). Mean percentage differences between actual and model fitted THM species were less than $+/-3 \%$. 
Variance of model output data to laboratory measured data may be attributable to errors in the model design but may also be due to errors in the chlorine decay test and analyses of THM compounds.

The approach in model development was to not limit applicability to any specific water and for this, key factors such as the formation of TTHM per chlorine reacted and the impact of $\mathrm{Br}$ on TTHM formation, were incorporated as input variables, along with key influencing water quality parameters ( $\mathrm{pH}$, temperature, bromide). The aim in this approach is to account for waters 'behaving differently' than those waters used for model development, where it is possible that other impacting factors exist but are as yet not identified.

Models reported in the literature for total THM include those that are of single fitted functions (e.g. kinetic, empirical power (Sohn et al. 2004), multivariate regression, artificial neural networks and physically based reaction models (e.g. first order) that incorporate parallel and/or consecutive reactions (Sun et al. 2009).

Although these models can match well the data used for model development, their applicability to full scale water works remains to be established. This may be a result of variance caused by the quality and reactivity of different waters and of the same water changing in quality over time and season, in the formation of TTHM and relative abundances of THM species. The model approach used in this study was of integration of consecutive and parallel reaction models (component models), that also include input factors that attempt to account for variance in reactivities from parameters such as bromide and organics present. This is to lower reliance on the need to update fixed model constants and reaction co-efficients, by having those of key reaction component models as input variables. The aim in this approach is to allow an operator at a water treatment plant or others not familiar with the model components and its function, to be able to calibrate its operation to mirror acquired laboratory data of TTHM and THM species formation for a selected water type. Once calibrated, the model may then be used to estimate TTHM and THM specie formation for waters blended as previously described or otherwise treated by conventional treatment processing for drinking water supply.

\section{CONCLUSIONS}

From data available to this study, relationships were established between the relative concentrations of bromide and the chlorine reacted with TTHM formation and the abundances of THM species. Affecting the formation of TTHM and the four THM species are also the parameters of temperature and $\mathrm{pH}$. The relationships of these on TTHM and THM specie formation were modelled as individual parameters following standardization of formations based on a selected set of nominal test conditions. Some relationships reported here are based on low resolution data, i.e. two values of each of temperature and $\mathrm{pH}$ within their impacting ranges were available. Greater resolution of data should allow for improved relationships being developed that describe trends of the effects of $\mathrm{pH}$ and temperature. Application of temperature and $\mathrm{pH}$ values beyond those used to develop the model (temperature $15^{\circ} \mathrm{C}-30^{\circ} \mathrm{C}$ and $\mathrm{pH}$ 7-8.5) is not justified. The modelling approach described in this paper is proposed as a concept that may be applied for estimation of the concentrations of TTHM and THM species for specific treated and chlorinated drinking waters.

\section{ACKNOWLEDGEMENTS}

The authors thank staff of the Australian Water Quality Centre, SA Water and the SA Water Centre for Water Management and Reuse, University of South Australia for supporting this study.

\section{REFERENCES}

ADWG (2004) Australian Drinking Water Guidelines, Australian Government, National Health and Medical Research Council; Natural Resource Management Council.

Daly, R., van Leeuwen, J. and Holmes, M. (2007) Modelling Coagulation to Maximise Removal of Organic Matter A Pilot Plant and Laboratory Based Study: Chemical Dose Prediction. CRC for Water Quality and Treatment, Salisbury, Research Report No. 36 Australia ISBN 18766 1661X

Eaton AE, Clesceri LS, Greenberg AE (1998) Standard Methods for The Examination of Water and Waste Water, 20th Edition, American Public Health Association, Washington, DC.

Fisher, I., Kastl, G., Sathasivan, A., Chen, P., van Leeuwen, J. A. And Daly, R. (2004). Tuning the enhanced coagulation process to obtain best chlorine and THM profiles in the distribution system. Water Science and Technology. Water Supply, 4 (4), 235-243.

Sohn, J., Amy, G., Cho, J., Leed, Y. and Yoon, Y. (2004) Disinfectant decay and disinfection by-products formation model development: chlorination and ozonation by-products. Water Research, 38, 2461-2478.

Sun, F., Chen, J., Tong, Q. and Zeng, S. (2009). Development and identification of an integrated waterworks model for trihalomethanes simulation. Science of the Total Environment. 407, 2077-2086. 
Uyak, V., Toroz, I. and Meric, S. (2005). Monitoring and modelling of trihalomethanes (THMs) for a water treatment plant in Istanbul. Desalination 176, 91-101.

Table 1. Comparison of laboratory data with model fitted data of THM species and TTHM of a conventionally treated South Australian water source without blending.

\begin{tabular}{|c|c|c|c|c|c|c|c|c|c|c|}
\hline Data & $\operatorname{Temp}^{\circ} \mathrm{C}$ & $\begin{array}{c}\mathrm{Br} \\
(\mathrm{mg} / \mathrm{L})\end{array}$ & pH & \begin{tabular}{|c|}
$\mathrm{Cl}_{2}$ \\
$\mathrm{Dose}$ \\
$(\mathrm{mg} / \mathrm{L}$ \\
\end{tabular} & $\begin{array}{c}\mathrm{Cl}_{2} \\
\text { Residual } \\
(\mathrm{mg} / \mathrm{L})\end{array}$ & $\begin{array}{c}\mathrm{CHCl}_{3} \\
(\mu \mathrm{g} / \mathrm{L})\end{array}$ & $\begin{array}{c}\mathrm{CHBrCl} 2 \\
(\mu \mathrm{g} / \mathrm{L})\end{array}$ & $\begin{array}{c}\mathrm{CHBr} 2 \mathrm{Cl} \\
(\mu \mathrm{g} / \mathrm{L})\end{array}$ & $\begin{array}{c}\mathrm{CHBr}_{3} \\
(\mu \mathrm{g} / \mathrm{L})\end{array}$ & $\begin{array}{c}\text { Total } \\
(\mu \mathrm{g} / \mathrm{L})\end{array}$ \\
\hline Lab Data 1 & 25 & 0.2 & 7.5 & 6 & 2.42 & 12 & 31 & 27 & 12 & 82 \\
\hline Model & & & & & & 16 & 24 & 33 & 15 & 88 \\
\hline Lab Data 2 & 25 & 0.2 & 7.5 & 6 & 1.61 & 22 & 34 & 35 & 15 & 106 \\
\hline Model & & & & & & 18 & 30 & 39 & 18 & 105 \\
\hline Lab Data 3 & 25 & 0.2 & 7.5 & 6 & 0.04 & 38 & 45 & 51 & 14 & 148 \\
\hline Model & & & & & & 24 & 38 & 51 & 23 & 136 \\
\hline Lab Data 4 & 25 & 0.2 & 7.5 & 5.5 & 1.74 & 13 & 28 & 37 & 19 & 97 \\
\hline Model & & & & & & 15 & 25 & 35 & 17 & 92 \\
\hline Lab Data 5 & 25 & 0.2 & 7.5 & 5.5 & 1.11 & 21 & 35 & 39 & 17 & 112 \\
\hline Model & & & & & & 17 & 29 & 40 & 19 & 105 \\
\hline Lab Data 6 & 25 & 0.2 & 7.5 & 5.5 & 0.06 & 23 & 54 & 59 & 22 & 158 \\
\hline Model & & & & & & 21 & 35 & 48 & 23 & 126 \\
\hline Lab Data 7 & 25 & 0.2 & 7.5 & 5 & 2.07 & 5 & 10 & 11 & 6 & 32 \\
\hline Model & & & & & & 11 & 20 & 29 & 15 & 75 \\
\hline Lab Data 8 & 25 & 0.2 & 7.5 & 5 & 1.15 & 12 & 26 & 37 & 20 & 95 \\
\hline Model & & & & & & 14 & 25 & 37 & 18 & 94 \\
\hline Lab Data 9 & 25 & 0.2 & 7.5 & 5 & 0.06 & 16 & 36 & 44 & 18 & 114 \\
\hline Model & & & & & & 17 & 31 & 45 & 23 & 116 \\
\hline Lab Data 10 & 25 & 0.4 & 7.5 & 5 & 2.3 & 4 & 11 & 27 & 23 & 65 \\
\hline Model & & & & & & 8 & 21 & 42 & 34 & 106 \\
\hline Lab Data 11 & 25 & 0.4 & 7.5 & 5 & 1.14 & 7 & 22 & 40 & 26 & 95 \\
\hline Model & & & & & & 11 & 28 & 54 & 45 & 138 \\
\hline Lab Data 12 & 25 & 0.4 & 7.5 & 5 & 0.01 & 11 & 42 & 64 & 39 & 156 \\
\hline Model & & & & & & 13 & 33 & 66 & 54 & 167 \\
\hline Lab Data 13 & 15 & 0.2 & 7.5 & 4.5 & 1.14 & 7 & 18 & 29 & 18 & 72 \\
\hline Model & & & & & & 10 & 21 & 33 & 26 & 91 \\
\hline Lab Data 14 & 15 & 0.2 & 7.5 & 4.5 & 0.08 & 14 & 37 & 48 & 22 & 121 \\
\hline Model & & & & & & 13 & 27 & 42 & 32 & 114 \\
\hline Lab Data 15 & 15 & 0.2 & 7.5 & 5 & 1.57 & 9 & 22 & 36 & 22 & 89 \\
\hline Model & & & & & & 12 & 23 & 33 & 24 & 92 \\
\hline Lab Data 16 & 15 & 0.2 & 7.5 & 5 & 0.41 & 19 & 37 & 36 & 13 & 105 \\
\hline Model & & & & & & 15 & 42 & 29 & 15 & 118 \\
\hline
\end{tabular}

\begin{tabular}{|c|c|}
\hline 1 & $\begin{array}{l}\text { Standardization of the effect of } \mathrm{Br} \text { on \%TTHM formation at } \mathrm{pH}(7 \text { and } 8.5) \text { and } \\
\text { temperature }\left(15^{\circ} \mathrm{C} \text { and } 30^{\circ} \mathrm{C}\right)\end{array}$ \\
\hline 2 & $\begin{array}{l}\text { Relationships established between } \mathrm{pH} \text { and temperature with \%TTHM formation, } \\
\% \mathrm{TTHM}=\mathrm{M} \mathrm{x} \mathrm{Br}+\mathrm{C} \text {, for } 15^{\circ} \mathrm{C} \text { and } 30^{\circ} \mathrm{C} \text { at } \mathrm{pH} 7 \text { and } 8.5\end{array}$ \\
\hline 3 & Integration of $\mathrm{pH}$ vs $\mathrm{Br}$ and temperature vs $\mathrm{Br}$ standardized models \\
\hline 4 & Using the above, determine the $\% \mathrm{TTHM}_{\mathrm{x}}$ percentage for a test water with $\mathrm{pH}_{\mathrm{i}}, \mathrm{T}_{\mathrm{j}}$ and $\mathrm{Br}_{\mathrm{k}}$ \\
\hline 5 & $\begin{array}{l}\text { Using a known data set of TTHMs, chlorine consumptions (various), Br (constant), } \mathrm{pH} \text { (constant) } \\
\text { and temperature (constant), calculate equivalent } \% \mathrm{TTHM}_{\mathrm{D}} \text { (based on above) and develop model of } \\
\text { TTHM formation per chlorine consumed }\end{array}$ \\
\hline 6 & $\begin{array}{l}\text { Calculate } \mathrm{R}_{1}=\% \mathrm{TTHM}_{\mathrm{x}} / \% \mathrm{TTHM}_{\mathrm{D}} \text {, and } \\
\mathrm{TTHM}_{\mathrm{x}}=\mathrm{R}_{1} \times\left[\left(\mathrm{C}_{\mathrm{THM}}, \mu \mathrm{g} \mathrm{THM} @ 1 \mathrm{mg} \mathrm{Cl}{ }_{2} \text { consumed }\right) \times \text { Total } \mathrm{Cl}_{2} \text { mg consumed }\right]^{\wedge} \mathrm{R}_{\mathrm{THM}}\end{array}$ \\
\hline
\end{tabular}


Figure 2. Develop steps of the TTHM model, incorporating the effects of bromide, temperature and $\mathrm{pH}$.

Table 2. Comparison of laboratory data with model fitted data of THM species and TTHM of a conventionally treated South Australian water source, following blending (75\% to $25 \%)$.

\begin{tabular}{|c|c|c|c|c|c|c|c|c|c|c|c|}
\hline Data & $\begin{array}{c}\text { Surface } \\
\text { Water } \\
\%\end{array}$ & $\begin{array}{c}\text { Temp } \\
{ }^{\circ} \mathrm{C}\end{array}$ & $\begin{array}{c}\mathrm{Br} \\
(\mathrm{mg} / \mathrm{L})\end{array}$ & pH & $\begin{array}{c}\text { Cl2 Dose } \\
(\mathrm{mg} / \mathrm{L})\end{array}$ & $\begin{array}{c}\mathrm{Cl}_{2} \\
\text { Residual } \\
(\mathrm{mg} / \mathrm{L})\end{array}$ & $\begin{array}{l}\mathrm{CHCl}_{3} \\
(\mu \mathrm{g} / \mathrm{L})\end{array}$ & $\begin{array}{c}\mathrm{CHBrCl} 2 \\
(\mu \mathrm{g} / \mathrm{L})\end{array}$ & $\begin{array}{c}\mathrm{CHBr} 2 \mathrm{Cl} \\
(\mu \mathrm{g} / \mathrm{L})\end{array}$ & $\begin{array}{l}\text { CHBr3 } \\
(\mu \mathrm{g} / \mathrm{L})\end{array}$ & $\begin{array}{c}\text { Total } \\
(\mu \mathrm{g} / \mathrm{L})\end{array}$ \\
\hline Lab Data 17 & $75 \%$ & 25 & 0.17 & 7.8 & 4.5 & 1.46 & 9 & 20 & 31 & 18 & 78 \\
\hline Model & & & & & & & 12 & 20 & 29 & 14 & 74 \\
\hline Lab Data 18 & $75 \%$ & 25 & 0.17 & 7.8 & 4.5 & 0.04 & 20 & 38 & 38 & 13 & 109 \\
\hline Model & & & & & & & 16 & 27 & 38 & 19 & 100 \\
\hline Lab Data 19 & $75 \%$ & 15 & 0.17 & 7.8 & 3.7 & 1.07 & 6 & 15 & 29 & 20 & 70 \\
\hline Model & & & & & & & 8 & 17 & 26 & 21 & 72 \\
\hline Lab Data 20 & $75 \%$ & 15 & 0.17 & 7.8 & 3.7 & 0.19 & 12 & 33 & 40 & 18 & 103 \\
\hline Model & & & & & & & 10 & 21 & 33 & 27 & 92 \\
\hline Lab Data 21 & $50 \%$ & 25 & 0.12 & 7.8 & 3.1 & 1.09 & 5 & 12 & 21 & 16 & 54 \\
\hline Model & & & & & & & 7 & 12 & 18 & 9 & 48 \\
\hline Lab Data 22 & $50 \%$ & 25 & 0.12 & 7.8 & 3.1 & 0.05 & 10 & 31 & 33 & 15 & 89 \\
\hline Model & & & & & & & 12 & 18 & 26 & 12 & 68 \\
\hline Lab Data 23 & $50 \%$ & 25 & 0.72 & 7.8 & 3.1 & 0.94 & 2 & 6 & 24 & 48 & 80 \\
\hline Model & & & & & & & 1 & 7 & 23 & 77 & 107 \\
\hline Lab Data 24 & $50 \%$ & 25 & 0.72 & 7.8 & 3.1 & $<0.1$ & 2 & 12 & 39 & 119 & 172 \\
\hline Model & & & & & & & 2 & 9 & 31 & 103 & 144 \\
\hline Lab Data 25 & $50 \%$ & 15 & 0.12 & 7.8 & 3.6 & 1.36 & 6 & 14 & 28 & 21 & 69 \\
\hline Model & & & & & & & 9 & 15 & 20 & 9 & 53 \\
\hline Lab Data 26 & $50 \%$ & 15 & 0.12 & 7.8 & 3.6 & 0.12 & 10 & 32 & 40 & 19 & 101 \\
\hline Model & & & & & & & 13 & 22 & 29 & 13 & 76 \\
\hline Lab Data 27 & $50 \%$ & 15 & 0.12 & 7.8 & 2.5 & 0.74 & 2 & 8 & 19 & 19 & 48 \\
\hline Model & & & & & & & 5 & 11 & 17 & 14 & 47 \\
\hline Lab Data 28 & $50 \%$ & 15 & 0.12 & 7.8 & 2.5 & 0.11 & 4 & 17 & 25 & 14 & 60 \\
\hline Model & & & & & & & 6 & 14 & 22 & 19 & 61 \\
\hline Lab Data 29 & $25 \%$ & 25 & 0.06 & 7.9 & 1.8 & 0.56 & 3 & 8 & 15 & 16 & 42 \\
\hline Model & & & & & & & 5 & 8 & 11 & 5 & 29 \\
\hline Lab Data 30 & $25 \%$ & 25 & 0.06 & 7.9 & 1.8 & 0.11 & 2 & 14 & 36 & 37 & 89 \\
\hline Model & & & & & & & 7 & 11 & 14 & 6 & 37 \\
\hline Lab Data 31 & $25 \%$ & 15 & 0.06 & 7.9 & 1.5 & 0.53 & 1 & 4 & 9 & 14 & 28 \\
\hline Model & & & & & & & 3 & 6 & 9 & 7 & 25 \\
\hline Lab Data 32 & $25 \%$ & 15 & 0.06 & 7.9 & 1.5 & 0.18 & 1 & 7 & 22 & 26 & 56 \\
\hline Model & & & & & & & 4 & 8 & 12 & 9 & 33 \\
\hline
\end{tabular}

\begin{tabular}{|c|c|}
\hline 1 & $\begin{array}{l}\text { Establishment of relationship between } \mathrm{Br} / \mathrm{Cl}_{2} \text { (reacted) and \% chloroform abundance, at known } \\
\text { temperatures }\end{array}$ \\
\hline 2 & $\begin{array}{l}\text { Establishment of relationship between } \mathrm{Br} / \mathrm{Cl}_{2} \text { (reacted) and \% bromoform abundance, at known } \\
\text { temperatures }\end{array}$ \\
\hline 3 & Temperature effects for each of the above determined and integrated into model \\
\hline 4 & Establishment of relationship between $\mathrm{Br} / \mathrm{Cl}_{2}$ (reacted) and ratio of $\mathrm{CHBr}{ }_{2} \mathrm{Cl} / \mathrm{CHBrCl}_{2}$ \\
\hline 5 & $\begin{array}{l}\text { For an input of } \mathrm{Br} / \mathrm{Cl}_{2} \text { reacted and using the above relationships, the percentages of the four } \\
\text { THM species can be calculated. From these percentages, the concentrations of each THM } \\
\text { specie }\left(\mu \mathrm{g} . \mathrm{L}^{-1}\right) \text { is calculated from the TTHMx }\left(\mu \mathrm{g} . \mathrm{L}^{-1}\right) \text {, previously determined }\end{array}$ \\
\hline
\end{tabular}

Figure 3. Development steps of the THM specie abundance model. 